\title{
Acute and subacute toxicity evaluation of hydroalcoholic extract from the stem bark of Bois Bande (Parinari campestris Aubl.1772) in rats
}

Venkatesan Sundaram*, Stephanie Mohammed ${ }^{2}$, M. R. Srinivasan ${ }^{3}$, Jenelle Johnson ${ }^{4}$, Rod Suepaul', Indira Pargass ${ }^{1}$, Chernell John', Danesha Ramdhanie ${ }^{1}$, Shiann Lallack', Esther Daniel ${ }^{1}$ and Lester Gilkes ${ }^{1}$

\begin{abstract}
Introduction: The bark of Bois Bande (Parinari campestris) is a popular aphrodisiac in the Caribbean that has been traditionally used for many years to restore sexual vitality, increase sperm count, and treat erectile dysfunction, without valid scientific data. Acute and 28-day subacute toxicity studies were conducted to evaluate the safety of the hydroalcoholic extract of P.campestris bark and to find a safe dose for human use in conventional medicine.

Methods: The acute toxicity study used a single oral dose of P.campestris extract at four separate doses, 5, 50, 300, and $2,000 \mathrm{mg} / \mathrm{kg}$, and was seen for 14 days, while the subacute toxicity study used a daily oral dose of P.campestris extract at 3 different doses, 100, 300, and $1000 \mathrm{mg} / \mathrm{kg} /$ day for 28 days.

Results: The $\mathrm{LD}_{50}$ of P.campestris extract was found to be greater than $2000 \mathrm{mg} / \mathrm{kg}$ in the acute toxicity study. P.campestris extract did not show toxicity at $1000 \mathrm{mg} / \mathrm{kg} /$ day in subacute toxicity trial; NOAEL was $1000 \mathrm{mg} / \mathrm{kg} / \mathrm{day}$ in rats. However, the body weight was increased in males.
\end{abstract}

Conclusion: In conclusion, $1000 \mathrm{mg} / \mathrm{kg}$ P.campestris extract can be considered safe and non-toxic in males.

Keywords: Bois Bande, Parinari campestris, Acute toxicity, Subacute toxicity

\section{Introduction}

Approximately $31-52 \%$ of the world's male population has met sexual issues linked to ejaculation disorders, erectile dysfunction, and suppressed sexual desire $[1,2]$. The World Health Organization has emphasized that not only the lack of disease, dysfunction, or sickness but also the satisfaction and positive role of sexual health are critical for sexual health [3]. The enhancement of sexual activity is believed to improve the satisfaction and self-

\footnotetext{
* Correspondence: venkatesan.sundaram@sta.uwi.edu;

drvenkat1971@gmail.com

${ }^{1}$ Department of Basic Veterinary Sciences, School of Veterinary Medicine,

Faculty of Medical Sciences, The University of the West Indies, St. Augustine, Trinidad and Tobago

Full list of author information is available at the end of the article
}

esteem of human relationships [4]. Consequently, the quest for natural aphrodisiacs that arouses sexual desire to enhance pleasure and performance has increased. This pursuit of happiness made many herb-based natural aphrodisiacs popular all over the world in recent years due to their low cost, easy availability, and promotion as having "no side effects." However, most of the products were not confirmed scientifically for their safety, side effects, and efficacy.

Natural products are widely acknowledged as safer in the health maintenance of developed countries and commonly used as self-medication even though no specific toxicological profile was provided [5]. The toxicity of herbal compounds has been documented in different

C C The Author(s). 2021 Open Access This article is licensed under a Creative Commons Attribution 4.0 International License, which permits use, sharing, adaptation, distribution and reproduction in any medium or format, as long as you give appropriate credit to the original author(s) and the source, provide a link to the Creative Commons licence, and indicate if changes were made. The images or other third party material in this article are included in the article's Creative Commons licence, unless indicated otherwise in a credit line to the material. If material is not included in the article's Creative Commons licence and your intended use is not permitted by statutory regulation or exceeds the permitted use, you will need to obtain permission directly from the copyright holder. To view a copy of this licence, visit http://creativecommons.org/licenses/by/4.0/ The Creative Commons Public Domain Dedication waiver (http://creativecommons.org/publicdomain/zero/1.0/) applies to the data made available in this article, unless otherwise stated in a credit line to the data. 
studies [6, 7]. The homeostasis and defense system of the human body was affected by delayed elimination of toxic chemicals in the natural products as well as longterm exposure of less harmful substances even at low doses [8]. So, the toxicity evaluation of the natural products becomes more important to ensure the safety of human health as the usage of these products increasing every day.

Parinari campestris Aubl.1772, a West Indian tropical tree plant belonging to the Chrysobalanaceae family, is commonly known as Bois bande or Bwa bandé along with other tree plants Richeria grandis and Roupala montana. The bark of these trees is highly reputed for their aphrodisiac properties in the Caribbean region. The P.campestris bark is used to restore sexual vitality, increase sperm count and counteract erectile dysfunction traditionally for many years [9]. In recent years, Bois bande has enjoyed great commercial popularity all over the world due to folklore, the internet, and tourism. However, there is no scientific data on its toxicity and side effects except an anecdotal warning that consumption at high doses may cause priapism, a persistent and painful erection lasting more than six hours with the loss of energy. Therefore, a toxicological evaluation of hydroalcoholic extract of Parinari campestris stem bark was done in rats, a primary predictive model for human effects in toxicity testing to assess its safety and finding a safe dose for the use of humans in conventional medicine.

\section{Materials and methods}

\section{Plant collection and extraction}

The fresh stem bark of P.campestris was collected from Mt. Harris Forest (10³0'38” N 616'ㄹ' W), Trinidad and Tobago with approval from the Forestry Division of the Ministry of Agriculture, Land and Fisheries, Trinidad, and Tobago. The plant was identified by technical staff at the National Herbarium of Trinidad and Tobago, Department of Life Sciences, University of the West Indies, St. Augustine, Trinidad, and Tobago, and voucher specimen (No. TRIN 50,648) was preserved. The samples were dried for 10 days and powdered. The powdered sample was extracted with $70 \%$ ethanol at room temperature $\left(23{ }^{\circ} \mathrm{C}\right)$ for 7 days with a material to solvent ratio of 1:4 (w: v) and vacuum filtered by a Buchner funnel. The process was repeated three times with fresh solvent each time and the combined filtrate was allowed to dry in a hot air oven at $37-40{ }^{\circ} \mathrm{C}$ and a dry hydroalcoholic extract was obtained with a yield percentage of $3.2 \mathrm{w} / \mathrm{w} \%$.

\section{Animal Care and Husbandry}

In the present study, sixty-three (63) healthy young adult (8-10 weeks old) Sprague Dawley rats of either sex (15 males for acute toxicity test and 24 males and 24 females for subacute toxicity test) with a weight range of 195$257 \mathrm{~g}$ were used. The animals were purchased from the Lab Animal Facility of the School of Veterinary Medicine, The University of the West Indies, St. Augustine, Trinidad, and Tobago. The rats were divided randomly by random numbers generated from Microsoft excel using = RAND () into groups according to the OECD guidelines (no.423 and no.407) and each group was housed in its cage in a dedicated experimental room at the School of Veterinary Medicine with a temperature of $22 \pm 3{ }^{\circ} \mathrm{C}$ and relative humidity of $50-60 \%$, as well as a 12-hour light/dark artificial light period. The animals were fed regular pellet feed and given free access to water. Before the experiment, all the animals were given a 7-day acclimatization period in the laboratory. The Campus Research Ethics Committee, The University of the West Indies, St. Augustine, Trinidad, and Tobago (No. CREC-SA.0072/11/2019) approved all animal procedures as per the National Institutes of Health's Guide for the Care and Use of Laboratory Animals [10].

\section{Acute toxicity study}

Research guideline no.423 of the Organization for Economic Cooperation and Development (OECD) was followed to conduct the acute oral toxicity analysis [11]. The study was performed on male rats because males were the intended sex in this research. A total of 15 male rats weighing 200 to $250 \mathrm{~g}$ were divided into five experimental groups of three rats each (control, 5, 50, 300 , and $2000 \mathrm{mg} / \mathrm{kg}$ groups). The limit test dose of $2000 \mathrm{mg} / \mathrm{kg}$ was selected as per the OECD Guidelines since no previous information was available on the toxicity of the P.campestris extract. The doses were prepared in sodium carboxymethyl cellulose (0.25\%) solution to form a uniform suspension and administered by oral gavage. The control group was administered with sodium carboxymethyl cellulose $(0.25 \%)$ solution whereas the other four groups received single oral doses of P.campestris extract at 5, 50, 300, and $2000 \mathrm{mg} / \mathrm{kg}$ daily at $9 \mathrm{am}$. On the first day after the gavage, all animals were monitored for mortality and general behavioral changes for $30 \mathrm{~min}, 2 \mathrm{~h}, 4 \mathrm{~h}, 6 \mathrm{~h}, 10 \mathrm{~h}$, and $24 \mathrm{~h}$, and then for a total of 14 days daily once. The median lethal dose $\left(\mathrm{LD}_{50}\right)$ was estimated as per OECD guideline No.423 [11]. All the animals were euthanized on the 15th day by intraperitoneal injection of pentobarbital sodium $(120 \mathrm{mg} / \mathrm{kg})$ [12], and post mortem examination was carried out to investigate the gross pathology.

\section{8-day subacute toxicity study}

The OECD Guideline no.407 was used to conduct the 28-day subacute toxicity test [13]. Forty-eight rats were divided into four groups at random, each with 12 
animals (6 males and 6 females). The $\mathrm{LD}_{50}$ was found to be greater than $2000 \mathrm{mg} / \mathrm{kg}$ as per the acute toxicity study. The control group was administered with carboxymethylcellulose $(0.25 \%)$ whereas the other three groups were received P.campestris extract daily by oral gavage at 100,300 , and $1000 \mathrm{mg} / \mathrm{kg}$ for 28 days daily at 9 am based on the estimated $\mathrm{LD}_{50}$ of the P.campestris extract. During treatment, irregular behavior, adverse clinical symptoms, and mortality were observed daily. The body weight, feed intake, and water consumption were recorded weekly. After an overnight fast, the animals were weighed and sedated with an intraperitoneal injection of ketamine hydrochloride $(80 \mathrm{mg} / \mathrm{kg})$. Following the sedation, the rats were anesthetized with intraperitoneal administration of pentobarbital sodium (40 mg/kg) [12], and blood samples were collected by an intracardiac puncture for hematological and biochemical analysis. All the animals were euthanized after the blood collection by intraperitoneal injection of pentobarbital sodium $(120 \mathrm{mg} / \mathrm{kg})$ [12]. The organs such as liver, kidney, spleen, heart, brain, lungs, testes, and ovaries were collected and weighed to calculate the relative organ weights (dividing each animal's organ weight by their body weight). The samples from the tissues were collected and fixed in $10 \%$ buffered formalin for histopathological examination.

\section{Hematological and Biochemical analysis}

The blood was collected in vacutainer tubes coated with Ethylenediaminetetraacetic acid (EDTA) for the hematological analysis. The blood parameters like White Blood Cell Counts (WBCs), Red Blood Cell Counts (RBCs), Hematocrit (HCT), Hemoglobin (Hb), Mean Corpuscular Volume (MCV), Mean Corpuscular Hemoglobin $(\mathrm{MCH})$, Mean Cell Hemoglobin Concentration (MCHC), Red Blood Cell Distribution Width (RDW), Reticulocytes (REL), Platelets (PLT), and Mean Platelet Volume (MPV) were estimated by using an automatic hematology analyzer (ProCyte Dx ${ }^{\text {tm }}$, Idexx Laboratories, Maine, USA).

Regarding biochemical analysis, solidified blood samples in non-EDTA coated tubes were centrifuged by a tabletop centrifuge (TJ-6, Beckman Coulter Inc., Brea, USA) at $1000 \mathrm{~g}$ at room temperature for $10 \mathrm{~min}$ to get sera for analysis. The serum biochemical parameters such as Serum Na, Serum Potassium (K), Sodium Potassium (Na: K) ratio, Serum Chloride $(\mathrm{Cl})$, Urea, Creatinine, Total Protein (TP), Albumin, Globulin, Albumin: Globulin (A: G) ratio, Glucose, and Cholesterol, Alkaline phosphatase (ALP), Alanine aminotransferase (ALT), Aspartate aminotransferase (AST), were analyzed by chemistry analyzer (BS 200, Mindray Medical International Company, Shenzhen, China).

\section{Histopathological analysis}

Tissue specimens were fixed in $10 \%$ buffered formalin and processed by routine histological processing. The histological sections of $4 \mu \mathrm{m}$ thickness were cut by using a rotary microtome (Finesse ME, Thermo Scientific Fisher Company, Waltham, USA) and stained with Haematoxylin and Eosin (H\&E). The sections were examined with the aid of an Olympus BX51 system microscope with a digital camera (Olympus Corporation, Tokyo, Japan).

\section{Statistical analysis}

All data were analyzed blindly and expressed as mean \pm SEM. Individual group data was checked for equality of variance by the Brown-Forsythe test. If the variance of the treatment groups was homogenous, then the parametric test, one-way ANOVA followed by the post-hoc Dunnett's multiple comparison test to compare the treatment group with the control group. If there was significant inequality of variance occurs, then the nonparametric test, equivalent to one-way ANOVA, the Kruskal-Wallis test was done followed by the post-hoc Dunnett's multiple comparison test to compare the treatment group with the control group. $p<0.05$ was considered significant. All statistical analysis was performed with GraphPad Prism (Version 9.0) software (GraphPad Software Inc, CA, USA).

\section{Results}

\section{Acute toxicity study}

The acute toxicity study revealed no mortality, morbidity, unusual behavior, and adverse clinical signs at all the tested single oral doses $(5,50,300$, and $2000 \mathrm{mg} / \mathrm{kg}$ ). The post mortem examination also did not show any gross pathological changes in all the animals studied. As a result, the extract's LD50 in rats was estimated to be greater than $2000 \mathrm{mg} / \mathrm{kg}$.

\section{8-day subacute toxicity study Behavior, Bodyweight, feed, and water intake}

The 28-day subacute toxicity study did not exhibit any mortality, morbidity, unusual behavior, and adverse clinical signs in all animals studied. The body weight increased gradually without significance from week 1-4 in all the animals of both sexes (Table 1). In males, a significant increase was noticed in the $100 \mathrm{mg} / \mathrm{kg}$ group on the third week, 100 and $300 \mathrm{mg} / \mathrm{kg}$ group on the 4 th week, and 100,300 , and $1000 \mathrm{mg} / \mathrm{kg}$ groups $(\mathrm{p}<0.05)$ on the day of sacrifice which was on 29th day (fasted body weight). In females, no statistically significant changes in the body weight were noticed except a decrease in the $1000 \mathrm{mg} / \mathrm{kg}$ group in fasted body weight $(p<0.05)$. The total body weight gain was significantly higher in the $100 \mathrm{mg} / \mathrm{kg}$ treated group in males and 
Table.1 Summary of weekly body weight changes ( $\mathrm{g}$ ) of rats in 28-day subacute toxicity study $(n=6)$

\begin{tabular}{|c|c|c|c|c|c|c|c|c|}
\hline \multirow[b]{2}{*}{ Weeks } & \multicolumn{4}{|l|}{ Males } & \multicolumn{4}{|l|}{ Females } \\
\hline & Control & $100 \mathrm{mg} / \mathrm{kg}$ & $300 \mathrm{mg} / \mathrm{kg}$ & $\begin{array}{l}1000 \mathrm{mg} / \\
\mathrm{kg}\end{array}$ & Control & $100 \mathrm{mg} / \mathrm{kg}$ & $300 \mathrm{mg} / \mathrm{kg}$ & $\begin{array}{l}1000 \mathrm{mg} / \\
\mathrm{kg}\end{array}$ \\
\hline Week 1 & $\begin{array}{l}209.08 \pm \\
25.22\end{array}$ & $241.18 \pm 7.70$ & $244.36 \pm 6.06$ & $257.35 \pm 7.90$ & $\begin{array}{l}195.79 \pm \\
5.02\end{array}$ & $192.03 \pm 7.81$ & $\begin{array}{l}210.46 \pm \\
5.24\end{array}$ & $\begin{array}{l}203.38 \pm \\
3.61\end{array}$ \\
\hline Week 2 & $\begin{array}{l}246.70 \pm \\
27.37\end{array}$ & $295.43 \pm 7.31$ & $294.03 \pm 8.83$ & $\begin{array}{l}268.45 \pm \\
12.73\end{array}$ & $\begin{array}{l}226.06 \pm \\
3.86\end{array}$ & $221.82 \pm 6.71$ & $\begin{array}{l}238.24 \pm \\
6.75\end{array}$ & $\begin{array}{l}216.88 \pm \\
7.04\end{array}$ \\
\hline Week 3 & $\begin{array}{l}272.01 \pm \\
27.66\end{array}$ & $337.37 \pm 7.08^{*}$ & $331.38 \pm 7.76$ & $296.94 \pm 7.09$ & $\begin{array}{l}247.47 \pm \\
4.23\end{array}$ & $\begin{array}{l}258.98 \pm \\
17.80\end{array}$ & $\begin{array}{l}248.24 \pm \\
6.75\end{array}$ & $\begin{array}{l}227.38 \pm \\
5.29\end{array}$ \\
\hline Week 4 & $\begin{array}{l}289.45 \pm \\
29.13\end{array}$ & $368.89 \pm 9.62^{*}$ & $\begin{array}{l}364.33 \pm \\
7.17^{*}\end{array}$ & $338.00 \pm 7.86$ & $\begin{array}{l}266.61 \pm \\
5.42\end{array}$ & $259.98 \pm 6.76$ & $\begin{array}{l}267.98 \pm \\
7.39\end{array}$ & $\begin{array}{l}245.04 \pm \\
5.44\end{array}$ \\
\hline Fasted body weight & $\begin{array}{l}293.83 \pm \\
29.50\end{array}$ & $\begin{array}{l}374.89 \pm \\
10.68^{*}\end{array}$ & $\begin{array}{l}367.83 \pm \\
9.38^{*}\end{array}$ & $\begin{array}{l}351.17 \pm \\
6.70^{*}\end{array}$ & $\begin{array}{l}269.50 \pm \\
4.66\end{array}$ & $256.50 \pm 6.05$ & $\begin{array}{l}264.83 \pm \\
5.87\end{array}$ & $\begin{array}{l}249.00 \pm \\
4.38^{*}\end{array}$ \\
\hline $\begin{array}{l}\text { Body weight gain (Week 4- } \\
\text { Week 1) }\end{array}$ & $\begin{array}{l}102.90 \pm \\
14.66\end{array}$ & $127.70 \pm 9.95^{*}$ & $\begin{array}{l}120.00 \pm \\
10.53\end{array}$ & $80.66 \pm 8.00$ & $70.82 \pm 6.55$ & $67.95 \pm 3.35$ & $57.53 \pm 7.60$ & $41.66 \pm 8.50^{*}$ \\
\hline
\end{tabular}

Note. Data was stated as Mean \pm Standard Error of the Mean (SEM). *Significantly different from the control group, $p<0.05$.

lower in the $1000 \mathrm{mg} / \mathrm{kg}$ treated group in females $(\mathrm{p}<0.05)$. No significant treatment-related change was observed in the feed and water intake of all the animals (Fig. 1).

\section{Gross pathology and Relative organ weights}

The post mortem examination did not show any abnormal changes or lesions in the internal organs of all the groups. No significant difference was noticed in the mean relative organ weights between control and treated groups $(p>0.05)$ except ovaries (Table 2$)$. The relative ovaries weight was significantly increased $(p>0.05)$ in 100 and $1000 \mathrm{mg} / \mathrm{kg}$ groups.

\section{Hematological Analysis}

The values of all the hematological parameters studied in all the animals were within the reference range for rats as shown in Table 3. The values of control and P.campestris extract-treated rats did not differ significantly $(p>0.05)$ except for a significant increase in PLT $(p<0.05)$ in the $300 \mathrm{mg} / \mathrm{kg}$ group (Table 3$).$

\section{Serum Biochemical Analysis}

All the biochemical parameters studied in the treated groups were within the reference range for rats. The values of control and P.campestris extract-treated rats did not differ significantly $(\mathrm{p}>0.05)$ except for a significant decrease in AST $(\mathrm{p}<0.05)$ in the $300 \mathrm{mg} / \mathrm{kg}$ group (Table 4$).$

\section{Histopathological analysis}

The histopathological analysis of major organs like liver, kidney, testes, brain, heart, lungs, testes, spleen, ovary, stomach, intestine, and skin of all the groups (control,
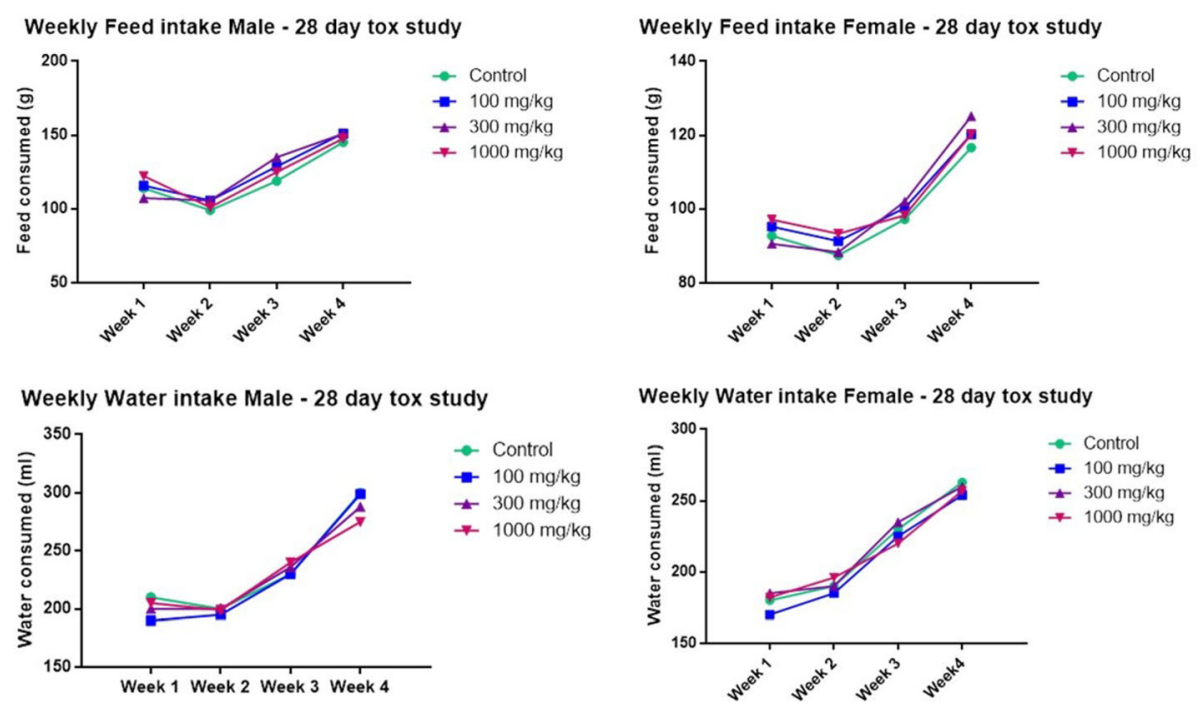

Fig. 1 The feed and water intake data of rats in 28-day subacute toxicity $(n=6)$ 
Table.2 Summary of relative organ weights $(\mathrm{g})$ in 28 -day subacute toxicity study $(n=12)$

\begin{tabular}{|c|c|c|c|c|}
\hline Relative organ weights (g) & Control & $100 \mathrm{mg} / \mathrm{kg}$ & $300 \mathrm{mg} / \mathrm{kg}$ & $1000 \mathrm{mg} / \mathrm{kg}$ \\
\hline Liver & $0.036 \pm 0.001$ & $0.039 \pm 0.001$ & $0.039 \pm 0.001$ & $0.035 \pm 0.001$ \\
\hline Kidneys & $0.009 \pm 0.000$ & $0.009 \pm 0.001$ & $0.010 \pm 0.001$ & $0.008 \pm 0.000$ \\
\hline Spleen & $0.002 \pm 0.000$ & $0.003 \pm 0.001$ & $0.003 \pm 0.001$ & $0.002 \pm 0.000$ \\
\hline Heart & $0.004 \pm 0.000$ & $0.004 \pm 0.001$ & $0.005 \pm 0.001$ & $0.003 \pm 0.000$ \\
\hline Lungs & $0.007 \pm 0.000$ & $0.006 \pm 0.001$ & $0.007 \pm 0.001$ & $0.006 \pm 0.001$ \\
\hline Brain & $0.006 \pm 0.000$ & $0.006 \pm 0.001$ & $0.007 \pm 0.001$ & $0.006 \pm 0.000$ \\
\hline Testes & $0.009 \pm 0.001$ & $0.009 \pm 0.001$ & $0.010 \pm 0.001$ & $0.008 \pm 0.000$ \\
\hline Ovaries & $0.0004 \pm 0.000$ & $0.002 \pm 0.000^{*}$ & $0.002 \pm 0.001$ & $0.001 \pm 0.000^{*}$ \\
\hline
\end{tabular}

Note. Data was stated as Mean \pm Standard Error of the Mean (SEM). *Significantly different from the control group, $p<0.05$

100, 300, and $1000 \mathrm{mg} / \mathrm{kg}$ ) was done. The histopathological evaluation showed normal architecture (Figs.2, 3, $4,5)$ comparable to the controls and there were no dose-dependent changes. The liver exhibited normal hepatic cords and sinusoids with typical hepatocytes and no signs of apoptosis (Fig.2 a-d). The kidney revealed regular renal corpuscles, tubules, and collecting ducts with normal interstitial tissue (Fig.2 e-h). The spleen showed normal red and white pulps (Fig.2 i-l). The heart myocardium revealed intact muscle bundles with normal muscle cells with typical vasculature (Fig.3 a-d). The regular neuronal architecture with glial cells was seen in the brain (Fig.3 e-h). Mild alveolar tissue congestion and alveolar thickening were noticed in all the groups including control (Fig.3 i-l). The testes showed the regular seminiferous tubules with progressive spermatogenesis and normal interstitial cells (Fig.4 a-d). The ovary showed normal follicular development and interstitium (Fig.4 e-h). The gastric mucosa, glands, and musculature were typical with the normal chief and parietal cells were found in the stomach (Fig.4 i-l). The intestinal tissue showed typical mucosa with villi lined by enterocytes and goblet cells (Fig.5 a-d). The skin showed intact epidermis and dermis with normal sebaceous and sweat glands with healthy hair follicles (Fig. 5 e-h).

\section{Discussion}

The P.campestris is used as a traditional medicine in curing erectile dysfunction without any scientific data on its toxicity profile to date. Since toxicological screening is a crucial tool to evaluate the safety of drugs or plants [14], acute and sub-acute oral toxicity studies of P.campestris extract were conducted. The rats are one of the most important animal models in toxicology. Hematological, respiratory, and cardiovascular adverse effects have the greatest cumulative comparability of toxicity in animals and humans [15]. However, the toxicity observed in animals is poorly correlated with certain adverse effects like hypersensitivity and idiosyncratic reactions in humans. Besides, side effects such as headache, stomach pain, dizziness, and visual hallucinations are also difficult to detect in animals. Moreover, it is difficult to extrapolate certain adverse effects between the species due to the pharmacokinetic variations between the species. However, rats are the primary predictive models for human effects in toxicity assessments [16]

Table.3 Summary of the hematological parameters of the rats in subacute 28-day subacute toxicity study $(n=12)$

\begin{tabular}{lllll}
\hline Parameters & Control & $\mathbf{1 0 0} \mathbf{~} \mathbf{g} / \mathbf{k g}$ & $\mathbf{3 0 0} \mathbf{~} \mathbf{g} / \mathbf{k g}$ & $\mathbf{1 0 0 0} \mathbf{~} \mathbf{g} / \mathbf{k g}$ \\
\hline WBC $\left(10^{9} / \mathrm{L}\right)$ & $8.42 \pm 0.75$ & $7.75 \pm 0.52$ & $8.70 \pm 0.54$ & $7.44 \pm 0.58$ \\
RBC $\left(10^{12} / \mathrm{L}\right)$ & $7.76 \pm 0.14$ & $8.09 \pm 0.13$ & $8.25 \pm 0.12$ & $7.89 \pm 0.22$ \\
HCT $(\mathrm{L} / \mathrm{L})$ & $0.41 \pm 0.01$ & $0.43 \pm 0.03$ & $0.43 \pm 0.01$ & $0.43 \pm 0.01$ \\
Hb (g/L) & $147.00 \pm 1.90$ & $152.70 \pm 2.30$ & $152.80 \pm 1.70$ & $151.3 \pm 2.02$ \\
MCV (fL) & $53.06 \pm 0.20$ & $53.19 \pm 0.33$ & $52.05 \pm 0.41$ & $54.42 \pm 0.86$ \\
MCH (pg) & $19.06 \pm 0.14$ & $18.88 \pm 0.08$ & $18.55 \pm 0.14$ & $19.30 \pm 0.47$ \\
MCHC (g/L) & $349.4 \pm 10.77$ & $354.30 \pm 2.18$ & $356.60 \pm 2.15$ & $354.4 \pm 3.44$ \\
RDW (\%) & $21.64 \pm 0.82$ & $20.30 \pm 0.24$ & $21.19 \pm 0.36$ & $21.52 \pm 0.29$ \\
Reticulocytes (REL) $\left(10^{9} / \mathrm{L}\right)$ & $4.30 \pm 0.27$ & $3.54 \pm 0.21$ & $3.47 \pm 0.22$ & $4.52 \pm 0.28$ \\
Platelets (PLT) $\left(10^{9} / \mathrm{L}\right)$ & $743.00 \pm 55.25$ & $942.20 \pm 50.12$ & $987.50 \pm 61.24^{*}$ & $731.40 \pm 92.78$ \\
MPV (fL) & $8.79 \pm 0.18$ & $9.08 \pm 0.11$ & $9.06 \pm 0.18$ & $9.09 \pm 0.09$ \\
\hline
\end{tabular}

Note. Data was stated as Mean \pm Standard Error of the Mean (SEM). *Significantly different from the control group, $p<0.05$ 
Table.4 Summary of the biochemical parameters of the rats in 28-day subacute toxicity study $(n=12)$

\begin{tabular}{|c|c|c|c|c|}
\hline Parameters & Control & $100 \mathrm{mg} / \mathrm{kg}$ & $300 \mathrm{mg} / \mathrm{kg}$ & $1000 \mathrm{mg} / \mathrm{kg}$ \\
\hline Serum $\mathrm{Na}(\mathrm{mmol} / \mathrm{L})$ & $142.70 \pm 0.49$ & $142.10 \pm 0.31$ & $141.90 \pm 0.42$ & $142.20 \pm 0.42$ \\
\hline Serum K (mmol/L) & $4.78 \pm 0.19$ & $5.13 \pm 0.40$ & $4.55 \pm 0.14$ & $5.12 \pm 0.22$ \\
\hline Sodium: Potassium ratio & $30.48 \pm 1.19$ & $29.20 \pm 1.72$ & $31.84 \pm 0.99$ & $28.35 \pm 1.22$ \\
\hline Serum Cl (mmol/L) & $106.00 \pm 0.66$ & $107.40 \pm 0.56$ & $105.80 \pm 0.33$ & $106.30 \pm 0.37$ \\
\hline Urea ((mmol/L) & $6.66 \pm 0.35$ & $6.18 \pm 0.22$ & $6.36 \pm 0.24$ & $6.18 \pm 0.11$ \\
\hline Creatinine $(\mu \mathrm{mol} / \mathrm{L})$ & $24.83 \pm 1.19$ & $26.07 \pm 1.73$ & $25.21 \pm 1.14$ & $22.38 \pm 0.85$ \\
\hline Total Protein (g/dL) & $70.75 \pm 0.52$ & $72.33 \pm 1.03$ & $71.36 \pm 0.87$ & $72.50 \pm 0.82$ \\
\hline Albumin (g/L) & $34.50 \pm 0.66$ & $35.45 \pm 0.49$ & $35.00 \pm 0.36$ & $36.42 \pm 0.66$ \\
\hline Globulin (g/L) & $36.25 \pm 0.87$ & $36.67 \pm 0.77$ & $36.36 \pm 0.90$ & $35.82 \pm 1.01$ \\
\hline Albumin: Globulin ratio & $0.96 \pm 0.04$ & $0.96 \pm 0.02$ & $0.97 \pm 0.03$ & $1.03 \pm 0.05$ \\
\hline Glucose (mmol/L) & $6.27 \pm 0.28$ & $7.06 \pm 0.33$ & $6.92 \pm 0.30$ & $7.01 \pm 0.59$ \\
\hline Cholesterol (mmol/L) & $1.48 \pm 0.07$ & $1.59 \pm 0.09$ & $1.61 \pm 0.07$ & $1.36 \pm 0.10$ \\
\hline ALP $(U / L)$ & $220.00 \pm 48.98$ & $167.50 \pm 12.86$ & $153.20 \pm 10.17$ & $170.50 \pm 9.61$ \\
\hline $\operatorname{ALT}(U / L)$ & $60.36 \pm 4.45$ & $69.36 \pm 8.76$ & $60.73 \pm 4.75$ & $69.50 \pm 6.45$ \\
\hline AST (U/L) & $172.80 \pm 12.07$ & $132.30 \pm 17.92$ & $99.45 \pm 6.78^{*}$ & $177.20 \pm 33.45$ \\
\hline
\end{tabular}

and the study was done on rats as per OECD guidelines $[11,13]$.

The phytochemical screening is usually done for the aphrodisiac plants to detect the phytoconstituents like carbohydrates, alkaloids, proteins, amino acids, tannins, phenolics, saponins, flavonoids, triterpenoids, steroids, glycosides, fixed oils, gums, and mucilages. So far no studies were conducted on P.campestris except a study that identified a new kaurene diterpene dimer [17]. However, the Parinari species showed a predominance of flavonoids glycosides based on myricetin, quercetin, and kaempferol [18]. The present study focuses only on the toxicological evaluation and the second phase of this ongoing research is aimed to carry out the phytochemical analysis and evaluation of the aphrodisiac potential of P.campestris.

The acute toxicity tests did not exhibit any mortality, morbidity, unusual behavior, and adverse clinical signs in all the animals. The P.campestris extract can therefore be considered non-toxic up to $2000 \mathrm{mg} / \mathrm{kg}$ single oral

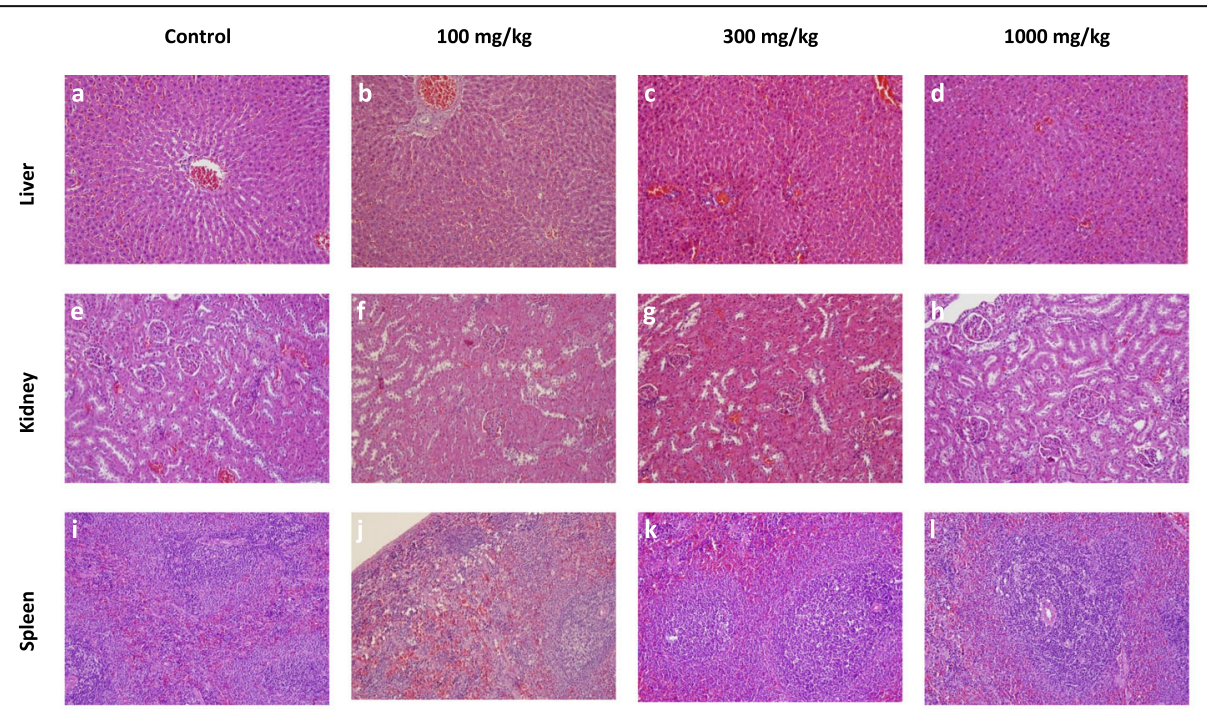

Fig. 2 The histopathology of liver, kidney, and spleen of the rats in 28-day subacute toxicity study. The liver (a-d) with typical hepatic cords with sinusoids with the central vein, the kidney (e-h) showed normal renal corpuscles, tubules, and collecting ducts, the spleen (i-I) with regular red and white pulp architecture (H\&E x 200). 


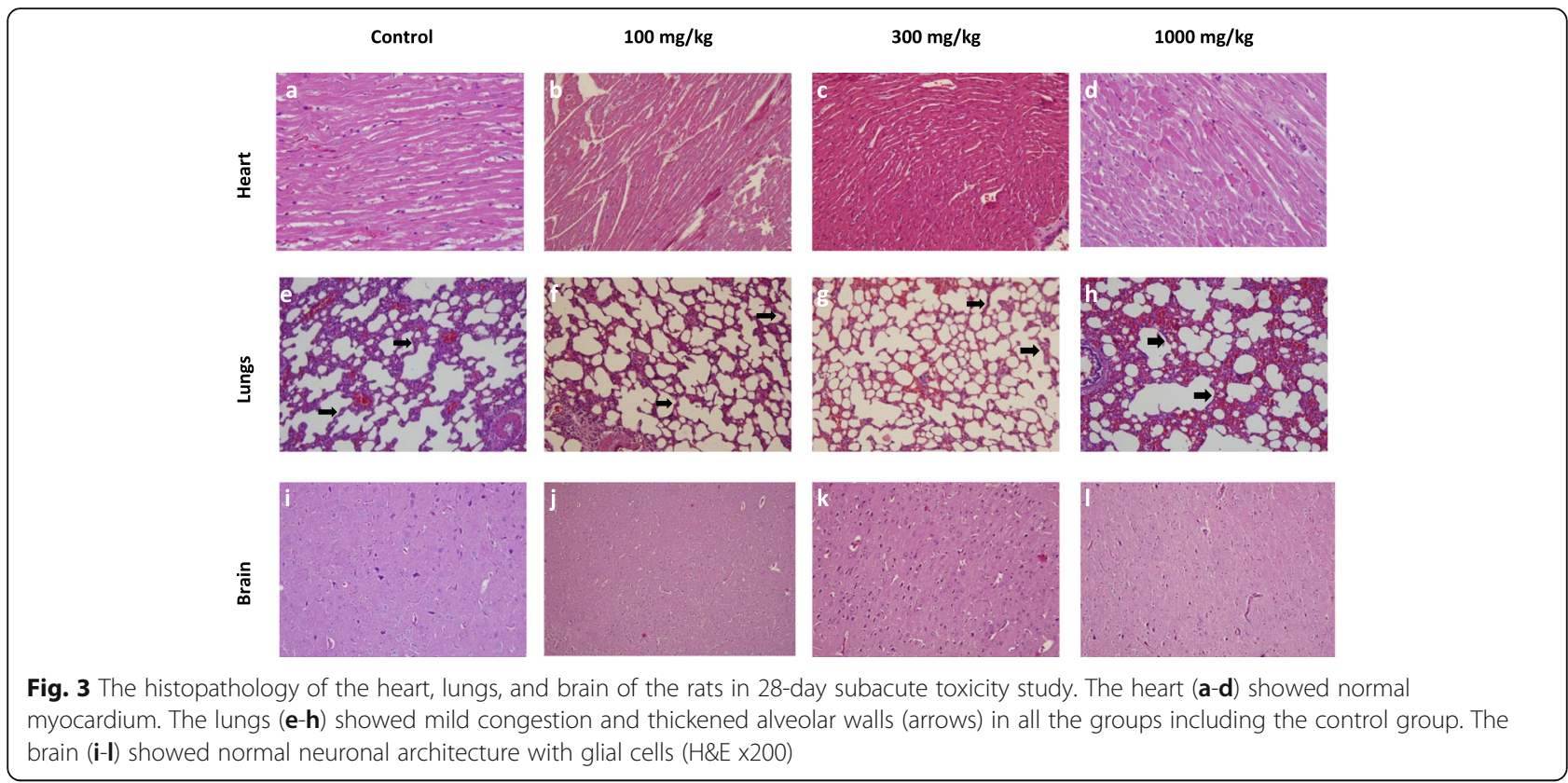

administration and can be classified as a Class 4 drug as per the acute toxicity classification criteria for substances $[13,19]$.

The P.campestris stem bark is consumed as an herbal brew (approximately 20-50 g of bark infused into alcohol for a week) or tea (a spoon of stem bark powder, roughly $5-8 \mathrm{~g}$, added to one liter of boiling water). It can be interpreted that the $\mathrm{LD}_{50}$ dose was much higher than the amount consumed in conventional medicine by considering the yield percentage $(3.2 \% \mathrm{w} / \mathrm{w})$ and the assumed $\mathrm{LD}_{50}(2000 \mathrm{mg} / \mathrm{kg})$ of the P.campestris extract in the present study. It should also be remembered that, relative to humans, rodents are more vulnerable to oral toxicity [20].

Toxicological assessments provide a dose-response relationship on potential health risks after repeated administrations. Thus, three different doses $(100,300$, and $1000 \mathrm{mg} / \mathrm{kg} /$ day) were tested in both sexes for 28 days in a subacute oral toxicity study. The non-significant increase in body weight every week indicated that the feed and water intake was proportionate to the normal growth and physiology. However, a significant increase in body weight in the $100 \mathrm{mg} / \mathrm{kg}$ group on week 3 and the 100 and $300 \mathrm{mg} / \mathrm{kg}$ groups on week 4 and in the
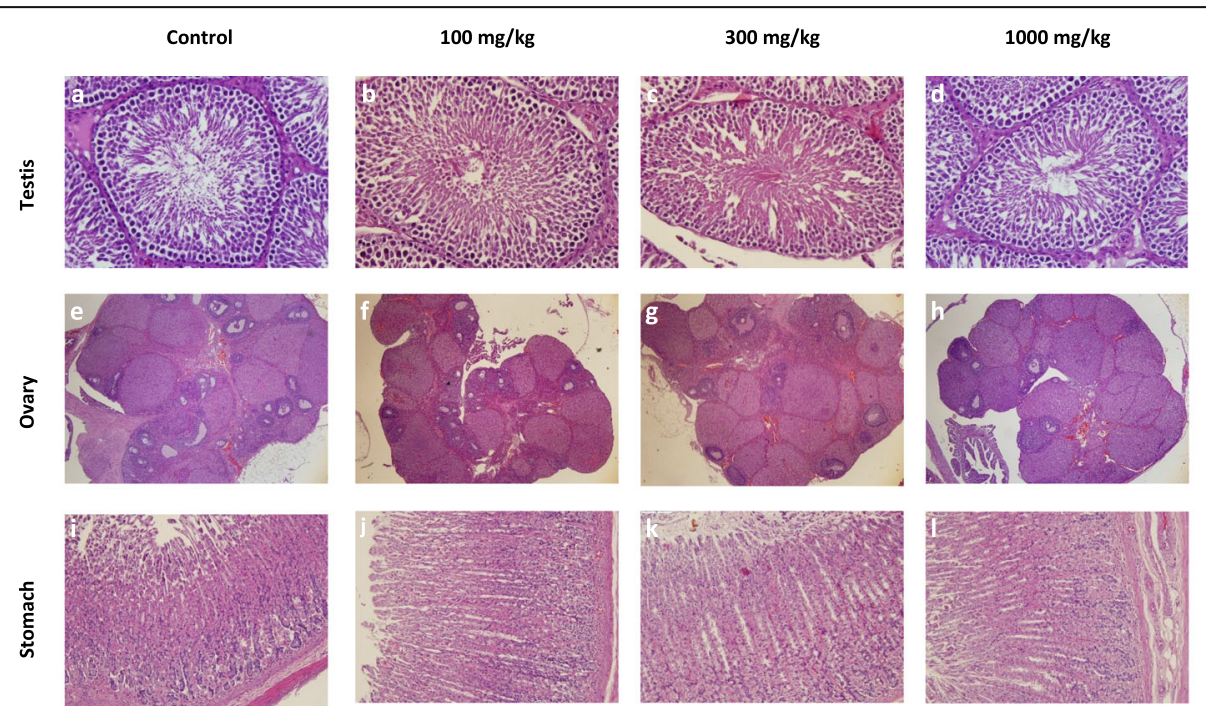

Fig. 4 The histopathology of the testes, ovary, and stomach of the rats in 28-day subacute toxicity study. The testes (a-d) showed regular seminiferous tubules and interstitial cells (H\&E x400), the ovary (e-h) showed normal follicular development, and interstitium (H\&E x40), the stomach (i-I) showed normal gastric mucosa and glands (H\&E X200) 

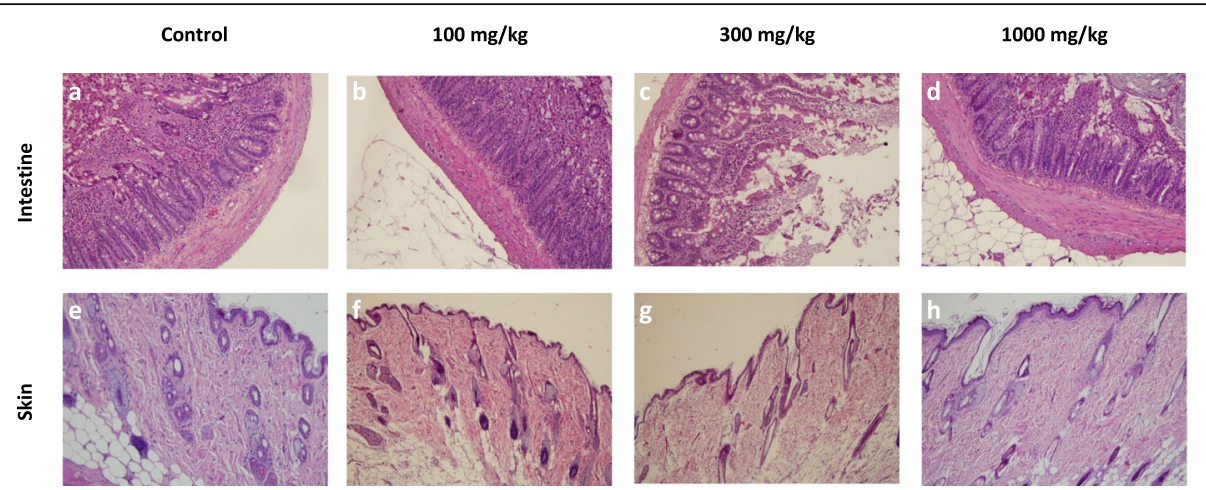

Fig. 5 The histopathology of the intestines and skin of the rats in 28-day subacute toxicity study. The intestine (a-d) showed typical mucosa with villi lined by enterocytes and goblet cells and the skin (e-h) showed the intact epidermis and dermis with normal sebaceous, sweat glands, and hair follicles (H\&E 200).

100,300 , and $1000 \mathrm{mg} / \mathrm{kg}$ groups on the day of sacrifice (fasted body weight) in males indicated the treatmentrelated effect. This increase was not considered as an adverse effect since it could be due to body fat accumulation [21] or muscular development during the treatment due to the possible aphrodisiac effect. In the females, the treatment-related effect was seen as a decrease in body weight and body weight gain in the high dose $(1000 \mathrm{mg} /$ $\mathrm{kg}$ ) group which could be a dose-dependent effect. It needs further investigation as body weight decrease was seen only in the $1000 \mathrm{mg} / \mathrm{kg}$ group So, the above results indicate that P.campestris extract increases the weight in males.

The detrimental effect of the test drug on metabolism is demonstrated by any major changes in food and water consumption [22]. No treatment-related effect was noticed in the feed ad water intake in the present study. Therefore, the P.campestris extract did not cause any change in appetite or thirst and alter the metabolic system on long-term administration.

The relative organ weight is considered one of the primary indicators of organ toxicity. The relative organ weights did not differ significantly except for the ovaries. The increase in relative ovaries weights was not dosedependent as the increase was seen only in 100 and $1000 \mathrm{mg} / \mathrm{kg}$ groups. Therefore, it is unlikely that P.campestris extract resulted in organ-level toxicity in rats.

The hematopoietic system is the common and sensitive target for toxic substances. It serves as a broad indicator of the overall physiological and pathological status of the body [23]. When translating data from animal research, the hematological parameters provide a higher level of predictability of toxicity in humans [15]. All the hematological parameters studied in the present study were within the reference range for rats [24] and the values of treated animals were comparable to control except for an increase in PLT in the $300 \mathrm{mg} / \mathrm{kg}$ group. The increased PLT value in the $300 \mathrm{mg} / \mathrm{kg}$ treated animals was also within the normal range and was not dosedependent, hence it was considered as an incidental finding. As a result, the P.campestris extract was found to have no harmful effects on the hemopoietic system. However, the present study did not evaluate all hematological parameters including Complete Blood Count $(\mathrm{CBC})$, clotting-related parameters, which must be further studied.

The liver function can be assessed by measuring the levels of protein, bilirubin, and liver enzymes [25]. The elevated levels of AST and ALT are usually associated with liver damage [26]. All the biochemical parameters studied in the present study showed no significant changes except a significant decrease in AST levels in the $300 \mathrm{mg} / \mathrm{kg}$ group. The most sensitive marker for hepatocyte damage is ALT, which is found mainly in the liver whereas AST is also found in red blood cells, cardiac and skeletal muscles, and kidneys apart from the liver. Further, the mean values of AST were low at the $300 \mathrm{mg} / \mathrm{kg}$ group whereas, at the $1000 \mathrm{mg} / \mathrm{kg}$ group, it was increased and levels were comparable with control. So, it can be considered biologically not significant and could be an incidental finding. This statement was further confirmed with normal liver histology in $300 \mathrm{mg} / \mathrm{kg}$ treated rats. So, it can be concluded that the P.campestris extract is not toxic to the liver.

The increased levels of blood urea nitrogen and creatinine can indicate the impaired kidney function [27]. In the present study, the values of urea, creatinine, sodium and potassium ions, glucose, and other parameters related to kidney function were within the normal range and did not differ significantly in all the animals. So, the P.campestris extract did not harm the kidney.

The histopathological examination is used to back up the hematological and biochemical findings [28]. All the organs showed normal architecture comparable to control in the histopathological study. Although some variations were noticed, they were minimal and matched the 
control group observations, and were not dosedependent. The lungs showed a thickened alveolar wall with mild congestion in all the groups including control animals, so it was not considered as a treatment-related effect. The results of the histopathological study validate the claim of P.campestris extract to be non-toxic.

Based on the above findings, the No Observed Adverse Effect Level (NOAEL) for P.campestris extract is considered as $1000 \mathrm{mg} / \mathrm{kg} /$ day. According to the FDA [29] guideline, the human equivalent dose (HED) based on the body surface area was computed as $1000 \mathrm{mg} / \mathrm{kg}$ divided by 6.2 , which is equal to $161 \mathrm{mg} / \mathrm{kg}$ body weight in humans, and $16.1 \mathrm{mg} / \mathrm{kg}$ body weight in humans is a safe dose of P.campestris extract by oral route in humans, recognizing the safety factor of 10 to HED. Therefore, for an average body weight of $60 \mathrm{~kg}$, the safe human dosage is $966 \mathrm{mg}(16.1 \times 60)$ or approximately $1 \mathrm{~g}$, which can be consumed orally for less than 28 days without any adverse effects in males.

Additional studies of genotoxicity, carcinogenicity, and teratogenicity [30] are also required to be done as they will strengthen the safety profile of P.campestris extract. This limitation, however, is suggested to be the potential course of our future research.

\section{Conclusions}

The acute and 28-day subacute oral toxicity studies of P.campestris extract were carried out in the rat model in the present study. The $\mathrm{LD}_{50}$ was greater than $2000 \mathrm{mg} / \mathrm{kg}$ for rats since the P.campestris extract did not reveal any mortality at all tested doses in the acute toxicity study. The 28-day subacute toxicity study did not exhibit any treatment-related adverse effects on the behavior, feed and water intake, relative organs weights, hematological, biochemical parameters, and gross and histopathology of organs in tested doses. However, 28-day oral administration increased the body weight in males. The No Observed Adverse Effect Level (NOAEL) was determined as $1000 \mathrm{mg} /$ $\mathrm{kg} /$ day. It is therefore recommended that P.campestris extract can be administered safely to men at approximately $1000 \mathrm{mg}$ (or) $1 \mathrm{~g} /$ day total dose for a man weighing $60 \mathrm{~kg}$ for a brief period of fewer than 28 days.

\section{Supplementary Information}

The online version contains supplementary material available at https://doi. org/10.1186/s40360-021-00522-w.

\section{Additional file 1:}

\section{Acknowledgements}

The authors thank the School of Graduate Studies and Research, The University of the West Indies, St. Augustine, Trinidad, and Tobago for the financial support of this research project through Campus Research and Publication Fund (No. CRP.3 NOV.19.8, 2019). The authors acknowledge the Forestry Division of the Ministry of Agriculture, Land, and Fisheries, Trinidad and Tobago for approval and assistance of the collection of the P.campestris stem bark in the forest. The authors thank Dr. Perumal Pandi Kumar, Scientist, Entomology Research Institute, Loyola College, Chennai, India for his valuable contribution during the initial period of the study. The authors also acknowledge Mr. Gerald Chandoo, Mr. Rakesh Bhukal, Dr. Lisa Maharaj, Dr. Alyssa Bally, Ms. Nalini Kalloo, Mr. Vashish Maharaj, Ms. Sian Baldeo, Ms. Kandice King, Mr. Andy Sookoo, and Mr. Trevor for their tremendous support during various phases of the experiment.

\section{Authors' contributions}

VS: Conceptualization; Funding acquisition; Investigation; Methodology; Project administration; Resources; Roles/Writing - original draft; SM: Data curation; Formal analysis; Investigation; Project administration; MRS: Conceptualization; Formal analysis; Supervision; Validation; review \& editing: J): Animal care; RS: Gross and Histopathological analysis; review \& editing; IP: hematological and biochemical analysis and CJ; DR; SL; ED and LG:

Collection and preparation of extract, conduction of trials. The author(s) read and approved the final manuscript.

\section{Funding}

This research was supported by the School of Graduate Studies and Research, The University of the West Indies, St. Augustine, Trinidad and Tobago through the Campus Research and Publication Fund (CRP.3 NOV.19.8, 209).

Availability of data and materials

All data are contained and described within the manuscript.

\section{Declarations}

Ethical approval and consent to participate

The animal studies were conducted according to the guidance of the National Institutes of Health's Guide for the Care and Use of Laboratory Animals (NRC, 2011) and approved by the Campus Research and Ethics Committee of the University of the West Indies for animal experimentation (No. CREC-SA.0072/11/2019).

The plant was collected with the permission of the Forestry Division of the Ministry of Agriculture, Land and Fisheries, Trinidad and Tobago, and identified at the National Herbarium of Trinidad and Tobago, Department of Life Sciences, University of the West Indies, St. Augustine, Trinidad, and Tobago, and voucher specimen (No. TRIN 50,648) was preserved. The dosages for the plant extract were calculated based on the OECD Guideline 423 for Acute Toxicity Study and based on these results, the 28-day Sub Acute toxicity study dosages were calculated.

The ARRIVE guidelines [31] were used for reporting the study and the checklist is added as additional file 1.

Consent for publication

All authors consent to the publication of this manuscript.

\section{Competing interests}

All authors declare that they have no competing of interest.

\section{Author details}

${ }^{1}$ Department of Basic Veterinary Sciences, School of Veterinary Medicine, Faculty of Medical Sciences, The University of the West Indies, St. Augustine, Trinidad and Tobago. ${ }^{2}$ Biochemistry Unit, Department of Preclinical Sciences, Faculty of Medical Sciences, Faculty of Science and Technology, The University of the West Indies, St. Augustine, Trinidad and Tobago. ${ }^{3}$ Department of Veterinary Pharmacology and Toxicology, Madras Veterinary College, Tamilnadu Veterinary and Animal Sciences University, Tamil Nadu, Chennai, India. ${ }^{4}$ Department of Clinical Veterinary Sciences, School of Veterinary Medicine, Faculty of Medical Sciences, The University of the West Indies, St. Augustine, Trinidad and Tobago. 
Received: 31 March 2021 Accepted: 15 September 2021

Published online: 25 September 2021

\section{References}

1. Rosen, R.C. Prevalence, and risk factors of sexual dysfunction in men and women. Curr. Psychiatry Rep. 2000; 2: 189-195.

2. Kotta S., Ansari S., Ali J. Exploring scientifically proven herbal aphrodisiacs. Phcog. Rev. 2013; 7(13): 1-10.

3. World Health Organization. Defining sexual health. Available from: http:// www.who.int/reproductivehealth/topics/sexual_health/sh_definitions/en/. 2015. [Accessed on 31st January 2021]

4. Montorsi, F., Guazzoni G., Rigatti, P., Pozza, G. Pharmacological management of erectile dysfunction. Drugs. 1995: 50(3): 465-479.

5. Adewale, O.B., Onasanya, A., Anadozie, S.O., Abu MF, Akintan, I.A., Ogbole, C. J., Olayide II., Afolabi, O.B., Jaiyesimi, K.F., Ajiboye, B.O., Fadaka, A.O. Evaluation of acute and subacute toxicity of aqueous extract of Crassocephalum rubens leaves in rats. J Ethnopharmacol. 2016; 188: 153-8.

6. Vaghasiya, Y.K., Shukla V.J., Chanda, S.V. Acute Oral Toxicity Study of Pluchea arguta Boiss Extract in Mice. J. Pharmacol. Toxicol. 2011; 6: 113-123.

7. Christapher, P.V., Parasuraman, S., Asmawi, M.Z., Murugaiyah, V. Acute and subchronic toxicity studies of methanol extract of Polygonum minus leaves in Spraque Dawley rats. Regul. Toxicol. Pharmacol. 2017:33-41.

8. Tsatsakis, A., Docea, A.O., Constantin, C., Calina, D., Zlatian, O., Nikolouzakis, T. K., Stivaktakis, P.D., Kalogeraki, A., Liesivuori, J., Tzanakakis, G., Neagu, M. Genotoxic, cytotoxic, and cytopathological effects in rats exposed for 18 months to a mixture of 13 chemicals in doses below NOAEL levels. Toxicol Lett. 2019; 316: 154-170

9. Amin S. Erectile dysfunction, in Saudek, C.S. (ed), Diabetes guide -Trinidad and Tobago, John -Hopkins, POC-IT center. 2010.

10. National Research Council (US) Committee for the Update of the Guide for the Care and Use of Laboratory Animals. Guide for the Care and Use of Laboratory Animals. 8th edition. Washington (DC): National Academies Press (US); 2011. Available from: https://www.ncbi.nlm.nih.gov/books/NBK54050/ doi: https://doi.org/10.17226/12910

11. OECD Test No. 423: Acute Oral toxicity - Acute Toxic Class Method, OECD Guidelines for the Testing of Chemicals, Secs. 4, OECD Publishing, Paris. 2002. https://doi.org/10.1787/9789264071001-en.

12. Hawk, C.T., Leary, S.L., Morris, T.H. Formulary for laboratory animals. Third edition. Blackwell Publishing, lowa.2005.

13. OECD Test No. 407: Repeated Dose 28-day Oral Toxicity Study in Rodents, OECD Guidelines for the Testing of Chemicals, Secs. 4, OECD Publishing, Paris. 2008. https://doi.org/10.1787/9789264070684-en.

14. Parasuraman S. Toxicological screening. J Pharmacol. Pharmacother. 2011; 2(2): 74-9.

15. Olson, H., Betton, G., Robinson, D., Thomas, K., Monro, A., Kolaja, G., Lilly, P., Sanders, J., Sipes, G., Bracken, W., Dorato, M., Van Deun, K., Smith, P., Berger, B., Heller, A. Concordance of the toxicity of pharmaceuticals in humans and animals. Regul. Toxicol. Pharmacol. 2000; 32(1): 56-67.

16. Shayne, C. G. Rodents model for toxicity testing and biomarkers. In "Biomarkers in Toxicology," Gupta, R.C(ed), Academic Press, London. 2014. https://doi.org/10.1016/B978-0-12-404630-6.00002-6.

17. Braca, A., Abdel-Razik, A.F., Mendez, J., Morelli, I. A new kaurane diterpene dimer from Parinari campestris. Fitoterapia.2005; 76; 614-619

18. Coradin, L., Giannasi, D.E., Prance, A.T. Chemosystematic studies in the Chrysobalanaceae. Flavonoids in Parinari. Britton. 1985; 37:169-178.

19. World Health Organization. The WHO recommended the classification of pesticides by hazard, and guidelines to classification, World Health Organization, Geneva (2009). https://www.who.int/publications/i/item/ 9789240005662. 2009. [Accessed on 31st January 2021].

20. Van Miert, A.S. Extrapolation of pharmacological and toxicological data based on metabolic weight. Arch Exp Veterinarmed. 1989; 43(4): 481-488.

21. Gautam, M.K., Goel, R.K. Toxicological study of Ocimum sanctum Linn leaves hematological, biochemical, and histopathological studies. J Toxicol. 2014; 12: 489-497

22. Attanayake, A.P., Jayatilaka, K., Pathirana, C., \& Mudduwa, L. Efficacy and toxicological evaluation of Coccinia grandis (Cucurbitaceae) extract in male Wistar rats. Asian Pac. J. Trop. Dis. 2013; 3(6): 460-466.

23. Li, X.R., Luo, Y.J., Wang, L.J., Li, Y.H., Shi, Y, B., Cui, Y., Xue, M. Acute and subacute toxicity of ethanol extract from Salvia przewalskii Maxim in rodents. J. Ethnopharmacol. 2010; 131(1): 110-115.
24. He, Q., Su, G., Liu, K., Zhang, F., Jiang, Y., Gao, J., Liu, L., Jiang, Z., Jin, M., Xie, $\mathrm{H}$. Sex-specific reference intervals of hematologic and biochemical analytes in Sprague-Dawley rats using the nonparametric rank percentile method. PLoS One. 2017; 20:12(12). doi: https://doi.org/10.1371/journal.pone.018983.

25. Peng, W.J., Xin, R.H., Luo, Y.J., Liang, G., Ren, L.H., Liu, Y., Wang, G.B., Zheng, J. F., 2016. Evaluation of the acute and subchronic toxicity of Aster tataricus L. F. Afr. J. Tradit. Complement. Altern. Med. 2016; 13(6): 38-53.

26. Josef, O., Ratner, M., Shaw, M., Bailey, W., Schomaker S. The current state of 424 serum biomarkers of hepatotoxicity. Toxicol. 2008; 245(3): 194-205.

27. Ezeja, M.I., Anaga A.O., Asuzu, I.U. Acute and sub-chronic toxicity profile of methanol leaf extract of Gouania longipetala in rats. J. Ethnopharmacol. 2014;151(3):1155-1164

28. Traesel, G.K., Menegati, S.E.L.T., dos Santos, A.C., Carvalho Souza, R.I., Villas Boas, G.R., Justi, P.N., Kassuya, C.A.L., Sanjinez Argandona, E.J., Oesterreich, S. A. Oral acute and subchronic toxicity studies of the oil extracted from pequi (Caryocar brasiliense, Camb.) pulp in rats. Food Chem. Toxicol. 2016; 97: 224-231.

29. US-FDA. Guidance for Industry "Estimating the Maximum Safe Starting Dose in Initial Clinical Trials for Therapeutics in Adult Healthy Volunteers," US-FDA, CDER. https://www.fda.gov/regulatory-information/search-fda-guidancedocuments/estimating-maximum-safe-starting-dose-initial-clinical-trials-thera peutics-adult-healthy-volunteers. July 2005.

30. Yoshino, S., Awa, R., Ohto, N., Miyake, Y., Kuwahara, H. Toxicological evaluation of tandardized Kaempferia parviflora extract: Sub-chronic and mutagenicity studies. Toxicol. Rep. 2019; 6: 544-549.

31. Kilkenny C, Browne WJ, Cuthill IC, Emerson M, Altman DG. Improving Bioscience research reporting: the ARRIVE guidelines for reporting animal research. PLoS Biol. 2010; 8: e1000412.

\section{Publisher's Note}

Springer Nature remains neutral with regard to jurisdictional claims in published maps and institutional affiliations.

Ready to submit your research? Choose BMC and benefit from:

- fast, convenient online submission

- thorough peer review by experienced researchers in your field

- rapid publication on acceptance

- support for research data, including large and complex data types

- gold Open Access which fosters wider collaboration and increased citations

- maximum visibility for your research: over $100 \mathrm{M}$ website views per year

At $\mathrm{BMC}$, research is always in progress.

Learn more biomedcentral.com/submissions 